\title{
Colonic disorders in adult cystic fibrosis
}

\author{
Hugh Chaun BM FRCP FRCPC
}

$\mathrm{H}$ Chaun. Colonic disorders in adult cystic fibrosis. Can J Gastroenterol 2001;15(9):586-590. By 1996, the median survival of patients with cystic fibrosis (CF) in North America had increased to 31 years. With the markedly improved life expectancy, many CF patients are now adults. There is an associated increased risk of certain colonic disorders, and the emergence of other previously unrecognized disorders, in adult CF patients. The distal intestinal obstruction syndrome (DIOS), which is more common in older patients, is a frequent cause of abdominal pain. Intussusception may complicate DIOS; other differential diagnoses include appendiceal disease, volvolus, Crohn's disease, fibrosing colonopathy and colonic carcinoma. The diagnosis of acute appendicitis, although uncommon in patients with CF, is often delayed, and appendiceal abscess is a frequent complication. The prevalence of Crohn's disease in CF has been shown to be 17 times that of the general population. Right-sided microscopic colitis is a recently recognized entity in $\mathrm{CF}$ of uncertain clinical significance. Fibrosing colonopathy has been confined mostly to children with CF, attributed to the use of high strength pancreatic enzyme supplements, but it has been reported in three adults. Nine cases of carcinoma of the large intestine have been reported worldwide, associated with an apparent excess risk of digestive tract cancers in CF. Despite high carrier rates of Clostridium difficile in patients with CF, pseudomembranous colitis is distinctly rare, but severe cases complicated by toxic megacolon have been reported. In these patients, watery diarrhea is often absent. Adult CF patients with refractory or unexplained intestinal symptoms merit thorough investigations.

Key Words: Adults; Colonic disorders; Cystic fibrosis

\section{Troubles du côlon chez les adultes atteints de mucoviscidose}

RÉSUMÉ : En 1996, la survie moyenne des patients atteints de mucoviscidose (ou FK pour fibrose kystique) en Amérique du Nord était passée à 31 ans. Compte tenu de cette nette amélioration de l'espérance de vie, de nombreux patients atteints de FK atteignent désormais l'âge adulte. Or, on note un risque accru à l'égard de certains troubles du côlon et l'émergence d'autres maladies qui n'avaient pas encore été notées chez les patients adultes atteints de FK. Le syndrome d'obstruction intestinale distale (SOID), qui est plus fréquent chez les patients plus âgés, est une cause fréquente de douleur abdominale. L'intussusception peut compliquer le SOID. D'autres diagnostics différentiels sont : l'appendicite, le volvulus, la maladie de Crohn, la colopathie fibrosante et le cancer du côlon. Le diagnostic de l'appendicite aiguë, bien que rare chez les patients atteints de SK, est souvent retardé et l'abcès de l'appendice est une complication fréquente. La maladie de Crohn serait 17 fois plus prévalente chez les patients atteints de SK que dans la population en général. La colite microscopique du côté droit est une entité qui a récemment été reconnue dans la FK. On ignore quelle est sa portée clinique. La colopathie fibrosante a surtout été observée chez les enfants atteints de mucoviscidose. Elle est attribuée à l'utilisation de suppléments enzymatiques pancréatiques à forte dose, mais on l'a également signalée chez trois adultes. Neuf cas de cancer du côlon ont été rapportés dans le monde, associés à un risque apparemment plus grand de cancer de l'appareil digestif dans la FK. Même si les patients atteints de FK sont souvent porteurs de Clostridium difficile, la colite pseudomembraneuse est rare, mais des cas graves, compliqués de mégacôlon toxique ont été dénombrés. Chez ces patients, la diarrhée liquide est souvent absente. Les patients adultes atteints de FK, qui présentent des symptômes intestinaux rebelles ou inexpliqués doivent être soumis à des analyses plus approfondies.

This paper was first presented at the Bockus International Society of Gastroenterology Scientific Congress, August 31 to September 3, 1998, Graz, Austria

Adult Cystic Fibrosis Clinic and Division of Gastroenterology, Department of Medicine, St Paul's Hospital, and University of British Columbia,

Vancouver, British Columbia

Correspondence and reprints: Dr H Chaun, Suite 1402 - 805 West Broadway, Vancouver, British Columbia V5Z 1 K1.

Telephone 604-872-0717, fax 604-872-7921, e-mail hchaun@compuserve.com

Received for publication November 29, 1999. Accepted November 29, 1999 
$\mathrm{C}^{\prime}$ ystic fibrosis $(\mathrm{CF})$ is the most common life-threatening inherited disease of white populations (1). One in every 20 or 30 white Canadians probably carries the CF gene, and approximately one in every 2000 or 3000 is born with CF in this population (2). CF is much rarer in nonwhite populations, and occurs in one in 17,000 black Americans (3), one in 80,000 Native Americans (4) and one in 100,000 Asians (5). Advances in the management of CF have markedly improved survival. Once confined to children, CF is now also a disease of adults. Before 1950, the median survival was one year (6). In Canada, the median survival age increased from 15 years in the 1970s to 28 years in the decade 1980 to 1989 . By 1996, the median survival had increased to 31 years, and 36\% of patients registered with the United States Cystic Fibrosis Foundation were adults (6). It has been estimated that patients with CF born today can have a life expectancy of beyond 40 years $(7,8)$.

Enhanced longevity is associated with increased prevalence of various colonic disorders and the emergence of others that were previously unrecognized. The increased incidence of Crohn's disease (9), the increased risk of cancer (10) and the occurrence of fibrosing colonopathy, now reported also in adults $(11,12)$, are examples.

\section{DISTAL INTESTINAL OBSTRUCTION SYNDROME}

CF is caused by abnormality of a gene on the long arm of chromosome 7 known as the cystic fibrosis transmembrane conductance regulator (CFTR) gene. It encodes a cAMPregulated chloride channel and is located on the apical membrane of many epithelial cells, including pancreatic tubules and intestinal crypt enterocytes (13). Ion transport abnormalities have been demonstrated in intestinal tissues of CF (14).

Defects in crypt chloride and fluid secretion cause the production of viscous intestinal contents in CF. Distal intestinal obstruction syndrome (DIOS), previously termed meconium ileus equivalent, results from the effects of pancreatic insufficiency and the intestinal secretion abnormality. Abnormal intestinal motility may also be a contributing factor (15). It is associated with impaction of inspissated mucofeculent contents in the terminal ileum, cecum and proximal colon. The reported incidence of DIOS varies widely. In an earlier review of adult patients with CF, DIOS occurred in $24 \%$ of patients (16). However, possibly following the introduction of microspheric pancreatic enzymes (17), DIOS was reported in only $4 \%$ of adolescent and adult patients with CF (18). The disorder may be precipitated by poor compliance to pancreatic enzyme therapy and postoperative use of opiate drugs. Recurrent colicky abdominal pain and a palpable mass in the right lower quadrant, with or without other evidence of intestinal obstruction, are characteristic features of DIOS. A plain abdominal radiograph shows the impacted fecal mass. Differential diagnoses include intussusception, volvulus, Crohn's disease, carcinoma and fibrosing colonopathy. Appendicitis and periappendiceal abscess must be considered in the presence of peritoneal signs. Ultrasound may help in the recognition of intussusception, appendiceal disease and fibrosing colonopathy. Water-soluble contrast enema (eg, Gastrografin; Bracco Diagnostics Canada Inc, Canada) is most helpful in diagnosis, and may aid in the treatment of DIOS and intussusception. A balanced iso-osmotic polyethylene glycol lavage solution (eg, Go-lytely; Pharmascience, Canada) is effective in treating DIOS (19). Adult patients may require several litres to clear the obstructive mass, and may need it repeated for two or three days.

Constipation is common in adults with CF - up to three times more frequent than DIOS (20). Sometimes it may complicate excessive doses of pancreatic enzymes or it may result from the sheer bulk of stool secondary to longstanding malabsorption (17). Intestinal dysmotility may be an aggravating factor. Careful adjustment of the pancreatic enzyme dosage, high fibre and increased fluid intake, and the use of mineral oil or lactulose are often helpful. DIOS needs to be considered in resistant patients.

\section{INTUSSUSCEPTION}

Intussusception is a rare complication of CF but occurs most commonly in older patients (20). It was reported in $5 \%$ of patients in one adult series and in $20 \%$ of those presenting with intestinal obstruction (16). A tenacious fecal bolus adherent to the mucosa may act as the lead point. The intussusception is frequently ileocolic in location (21). It may occur as a complication of DIOS and is often recurrent. Its diagnostic evaluation and management have been described under DIOS. Failure to reduce the intussusception or suspicion of appendiceal disease are indications for laparotomy.

Intestinal volvulus complicating $\mathrm{CF}$ has been reported in patients with intestinal obstruction and a history of abdominal surgery (17).

\section{APPENDICITIS AND APPENDICEAL ABSCESS}

Despite the postmortem findings that the appendiceal lumen is often swollen and obstructed by inspissated eosinophilic secretions, acute appendicitis is an uncommon complication of $\mathrm{CF}$, occurring in $1 \%$ to $2 \%$ of patients $(22,23)$. However, the difficulty and delay in diagnosis may lead to serious complications such as perforation and chronic appendiceal abscess (24). Acute appendicitis in CF occurs over a wide age range, including adults (22). In older patients, the large, distended appendix may act as a lead point for intussusception (22). The diagnosis of appendiceal disease in CF may be masked by antibiotic therapy. The clinical presentation may mimic DIOS, intussusception and Crohn's disease (17). Laparotomy must be considered in the presence of tenderness, guarding, and leukocytosis or fever, if diagnostic imaging studies are unhelpful.

\section{CROHN'S DISEASE}

An extensive review of the gastrointestinal manifestations of CF in 1981 (21) noted that Crohn's disease had been reported in only two patients with CF. With the improved 
life expectancy of CF patients, the coexistence of inflammatory bowel disease is expected to increase. Crohn's disease has now been reported in at least 14 CF patients, three of whom presented at the ages of 17,18 and 30 years, respectively $(25,26)$. Twelve of the 14 patients had colonic involvement, including eight with ileocolitis. In a survey of 52 CF clinics in the United States involving 11,321 patients (27), 28 patients were reported to have inflammatory bowel disease, of whom 25 had Crohn's disease. The prevalence of Crohn's disease in this series $\left(221\right.$ of $\left.10^{5}\right)$ was estimated to be 17 times higher than that in the general population.

Among 277 patients registered at the British Columbia Adult CF Clinic from 1980 to 1998, there were two patients with Crohn's disease (26). The first, a man now 35 years of age, was diagnosed with CF at age four months. Two sisters died of CF at the ages of one and four years. He presented with intense anal pain, markedly firm and tender perianal skin tags, and a perianal fistula at age 18 years. A rectal biopsy showed chronic active inflammation and noncaseating granulomata. He has since developed a rectal stricture complicating chronic acute disease in the left colon. The second patient, a woman now 39 years of age, was diagnosed with CF at age 18 years, based on abnormal sweat electrolytes and characteristic pattern of recurrent respiratory infections and sinusitis. She was shown to have Crohn's disease at age 30 years, complicated by an enterovesical fistula.

Because the symptoms and signs may mimic those of other intestinal disorders associated with CF, such as DIOS, there was a delay in diagnosis in most cases of Crohn's disease in patients with CF. The basis of the apparent susceptibility of CF patients to Crohn's disease remains speculative. Increased intestinal permeability has been demonstrated in patients with CF (28). It has been suggested that impaired protein digestion due to the lack of proteases in patients with CF may lead to a high antigenic load, which may injure the intestinal mucosa (25). However, the etiology of Crohn's disease remains an enigma.

\section{RIGHT-SIDED MICROSCOPIC COLITIS}

In a retrospective review of the pathology findings in 19 adult CF patients who had colonoscopy and biopsies for various indications, including 10 with abdominal pain, 14 were shown to have right-sided microscopic colitis (29). The findings were similar in all cases. The cecum was always involved, the ascending colon mostly and the transverse colon rarely. The process was diffuse. Abnormalities included crypt atrophy and distortion with irregular branching, crypt mucin depletion with features of regenerative activity, cryptitis, occasional crypt abscesses and increased chronic inflammatory cells in the lamina propria. Eosinophils were not a feature except in three cases. Fibrosis was not identified. All cases had minor mucus plugging of crypts, but this was not like DIOS. The pathology findings did not suggest fibrosing colonopathy, and the clinical course was not indicative of idiopathic inflammatory bowel disease. The pathogenesis of the right-sided microscopic colitis demonstrated in these patients is unknown. Perhaps it may be related in some way to the cell membrane lipid imbalance recently observed in CF-regulated tissues, in which there was a marked increase in the arachidonic acid to docosahexanoic acid ratio (30), because arachidonic acid is known to play an important role in regulating inflammation. The clinical and long term significance of the findings are not known. Diarrhea was not a feature of the patients.

\section{FIBROSING COLONOPATHY}

Cases of colonic strictures (now termed fibrosing colonopathy) complicating CF were first reported in 1994 (31). There was an apparent dose-related association between high strength pancreatic enzyme preparations and fibrosing colonopathy (32). Data from the United States Cystic Fibrosis Foundation subsequently revealed 35 cases (33), and the United Kingdom Cystic Fibrosis Registry revealed an additional 14 cases (32). The majority of patients were children under 15 years of age, but fibrosing colonopathy has now been reported in three adults with CF $(11,12)$. Its clinical presentation may mimic that of DIOS, with abdominal pain and features of intestinal obstruction, but it fails to respond to the usual medical management of DIOS. Some patients may have symptoms of colitis, with diarrhea containing blood. Chylous ascites has been described (34); obstruction of mesenteric lymphatic vessels has been suggested as a possible cause. Abdominal ultrasound may provide the diagnosis, but barium enema is more reliable (35). The characteristic radiographic features are colonic stricture, longitudinal shortening of the ascending colon and abnormal haustra. The process first affects the right colon but may occasionally involve the distal colon extensively without skip areas, in contrast to Crohn's disease. Treatment involves surgical resection, and the diagnosis is confirmed by the pathognomonic histopathological findings (32). Long stenotic segments result from submucosal thickening due to fibrosis. The epithelium is generally intact with very little inflammatory change (31). The methylacrylic acid copolymer in the enteric coating of microencapsulated enzyme preparations may be the causal factor in the etiology of fibrosing colonopathy (36). Because of the apparent strong relationship between the introduction of high dose lipase enzymes and the advent of fibrosing colonopathy, a recent United States consensus committee recommended that all patients with CF, including adults, take less than $2500 \mathrm{U}$ of lipase $/ \mathrm{kg} / \mathrm{meal}$ to avoid this complication (33).

\section{CARCINOMA}

Although the overall incidence of malignant disease in patients with CF is within the expected range, their risk of cancers in the digestive tract is significantly increased $(10,37)$. This excess risk is confined to adults. For CF patients 20 to 29 years old, the odds ratio for all gastrointestinal cancers is 20.1 (10). Nine of 24 gastrointestinal 
cancers reported worldwide were in the large intestine (10). Details of these patients were not presented. Two patients with colonic carcinoma were reported from the British Columbia Adult CF Clinic (38). Both patients were 31 years of age when the carcinoma was diagnosed. In this age group, carcinoma of the colon is distinctly rare in the normal population (39). Incidentally, the cancer was located in the midtransverse colon in both patients. Abdominal pain, including the DIOS (16) and iron deficiency (40) are common in patients with CF. The first patient presented with recurrent abdominal pain that mimicked DIOS. The second patient had a severe anemia that had been wrongly diagnosed. The diagnosis of colonic carcinoma in both patients was consequently delayed. A heightened awareness of gastrointestinal cancers is clearly important in the management of adult CF patients with unexplained persistent gastrointestinal symptoms.

It has been postulated that the increased risk of cancers in the digestive tract compared with other organs in patients with CF may be related to the differential expression of the CFTR gene in the gastrointestinal system (10). Another explanation is that the effect of the CF process may lead to chronic pathological changes in the digestive tract, which predispose patients to malignancy. An example is Barrett's esophagus, which has been reported in CF patients (41). Antioxidant (selenium or vitamin E) deficiency (42), or an interaction between the CF gene and an oncogene (10) are other suggested hypotheses.

\section{PSEUDOMEMBRANOUS COLITIS}

Antibiotics are frequently used in the management of patients with CF. Although the carrier rates of Clostridium difficile in patients with CF have been shown to be as high

\section{REFERENCES}

1. Steinberg A, Brown D. On the incidence of cystic fibrosis of the pancreas. Am J Hum Genet 1960;12:415-24.

2. Forstner G, Crozier DN, Sturgess JM. Cystic fibrosis: present status and future prospects in detection of patients and carriers. Can Med Assoc J 1975;113:550-6.

3. Welsh MJ, Tsui L-C, Boat TF, et al. Cystic fibrosis. In: Scriver CR, Beaudet AL, Sly WS, et al, eds. Metabolic Basis of Inherited Disease, 7th edn. New York: McGraw-Hill, 1995;3799.

4. Wilmott RW, Fiedler MA. Recent advances in the treatment of cystic fibrosis. Pediatr Clin North Am 1994;41:431-51.

5. Taylor GR, Farmery SM. Single gene disorders affecting the gastrointestinal tract. Gut 1993;34:433-6.

6. Yankaskas JR, Knowles MR. Cystic Fibrosis in Adults. Philadelphia: Lippincott-Raven, 1999:xiii.

7. FitzSimmons SC. The changing epidemiology of cystic fibrosis. J Pediatr 1993;122:1-9.

8. Elborn JS, Shale DJ, Britton JR. Cystic fibrosis: current survival and population estimates to the year 2000. Thorax 1991;46:881-5.

9. Lloyd-Still JD. Cystic fibrosis, Crohn's disease, biliary abnormalities, and cancer. J Pediatr Gastroenterol Nutr 1990;11:434-7.

10. Neglia JP, FitzSimmons SC, Maisonneuve P, et al. The risk of cancer among patients with cystic fibrosis. N Engl J Med 1995;332:494-9.

11. Enns R, May G, Urbanski S, et al. Colonic strictures in two adults with cystic fibrosis. Can J Gastroenterol 1996;10(Suppl A):8A. (Abst F66)

12. Hausler M, Meilicke R, Biesterfeld S, Heimann G. First adult patient with fibrosing colonopathy. Am J Gastroenterol 1998;93:1171-2.

13. Strong TV, Boehm K, Collins FS. Localization of cystic fibrosis transmembrane conductance regulator in $\mathrm{mRNA}$ in the human as $50 \%(43,44)$, pseudomembranous colitis appears to be distinctly rare. The first case, involving a 29-year-old man, was reported in 1992 (44). In a subsequent report of five patients with a striking absence of watery diarrhea, the important role of computed tomography scan in delineating the correct diagnosis was emphasized (45). The absence of diarrhea and the occurrence of abdominal distension may be manifestations of complicating toxic megacolon. An example of this in a patient with CF was presented recently (46). The patient required emergency surgical intervention.

The marked discrepancy between the frequent carrier rate and the rare occurrence of pseudomembranous colitis in CF may be related to CFTR-mediated chloride channel unresponsiveness to $\mathrm{C}$ difficile toxin (47), in a similar manner to the cholera enterotoxin (48).

\section{CONCLUSIONS}

Colonic disorders in CF predispose patients to significant morbidity. Similarities in their clinical presentations may cause delay in diagnosis and management. The coexistence of two disorders in the same patient may further confuse the diagnostic evaluation. With the increased longevity of patients with CF, adult gastroenterologists need to be vigilant in the recognition of atypical presentations and the increased risks of certain disorders affecting the colon in $\mathrm{CF}$ patients. Adult CF patients with refractory or unexplained intestinal symptoms merit thorough investigations.

ACKNOWLEDGEMENT: I am indebted to Dr David Owen, Department of Pathology, University of British Columbia, for his invaluable help in providing the histopathology data on rightsided microscopic colitis.

gastrointestinal tract by in situ hybridization. J Clin Invest 1994;93:347-54.

14. Gowen CW Jr, Gowen MA, Knowles MR. Colonic transepithelial potential difference in infants with cystic fibrosis. J Pediatr 1991;118:412-5.

15. Dalzell AM, Freestone NS, Billington D, Heaf DP. Small intestinal permeability and orocaecal transit time in cystic fibrosis. Arch Dis Child 1990;65:585-8.

16. di Sant'Agnese PA, David PB. Cystic fibrosis in adults: 75 cases and a review of 232 cases in the literature. Am J Med 1979;66:121-32

17. Gaskin KJ. Intestines. In: Yankaskas JR, Knowles MR, eds. Cystic Fibrosis in Adults. Philadelphia: Lippincott-Raven, 1999:325-42.

18. Andersen HO, Hjelt K, Waever E, Overgaard K. The age-related incidence of meconum ileus equivalent in a cystic fibrosis population: the impact of high-energy intake. J Pediatr Gastroenterol Nutr 1990;11:356-60.

19. Cleghom GJ, Stringer DA, Forstner GG, Durie PR. Treatment of distal intestinal obstruction syndrome in cystic fibrosis with a balanced intestinal lavage solution. Lancet 1986;i:8-11.

20. Durie PR. Cystic fibrosis: gastrointestinal and hepatic complications and their management. Int Semin Paediatr Gastroenterol Nutr 1993;2:3-9.

21. Park RW, Grand RJ. Gastrointestinal manifestations of cystic fibrosis: a review. Gastroenterology 1981;81:1143-61.

22. Coughlin JP, Gauderer MWL, Stem RC, Doershuk CF, lzant RJ, Zollinger RM. The spectrum of appendiceal disease in cystic fibrosis. J Pediatr Surg 1990;25:835-9.

23. Shields MD, Levison H, Reisman JJ, Durie PR, Canny GJ. Appendicitis in cystic fibrosis. Arch Dis Child 1990;65:307-10. 
24. Allen ED, Pfaff JK, Taussig LM, et al. The clinical spectrum of chronic appendiceal abscess in cystic fibrosis. Am J Dis Child 1992;146:1190-3.

25. Lloyd-Still JD. Crohn's disease and cystic fibrosis. Dig Dis Sci 1994;39:880-5.

26. Chaun H, Nakielna EM, Burdge DR. Crohn's disease in cystic fibrosis. XIth International Cystic Fibrosis Congress, Dublin, August 22-27, 1992;MP79. (Abst)

27. Lloyd-Still JD. Crohn's accounts for increased prevalence of inflammatory bowel disease (IBD) in CF. Pediatr Pulmonol Suppl 1992;8:307-8. (Abst)

28. Leclercq-Foucart J, Forget PP, Van Cutsem JL. Lactulose-rhamnose intestinal permeability in children with cystic fibrosis. J Pediatr Gastroenterol Nutr 1987;6:66-70.

29. Chaun H, Owen D. Cystic fibrosis is a cause of right-sided microscopic colitis. Can J Gastroenterol 1998;12(Suppl A):118A. (Abst)

30. Freedman SD, Alvarez JG. Pathogenesis of pancreatic disease in cystic fibrosis. Pediatr Pulmonol Suppl 1999;19:129. (Abst)

31. Smyth RL, Van Velzen D, Smyth AR, Lloyd DA, Heaf DP. Strictures of ascending colon in cystic fibrosis and high-strength pancreatic enzymes. Lancet 1994;343:85-6.

32. Smyth RL, Ashby D, O'Hea U, et al. Fibrosing colonopathy in cystic fibrosis: results of a case-control study. Lancet 1995;346:1247-51.

33. Borowitz DS, Grand RJ, Durie PR, et al. Use of pancreatic enzyme supplements for patients with cystic fibrosis in the context of fibrosing colonopathy. J Pediatr 1995;127:681-4.

34. Pettei MJ, Leonidas JC, Levine JJ, Gorvoy JD. Pancolonic disease in cystic fibrosis and high-dose pancreatic enzyme therapy. J Pediatr 1994;125:587-9.

35. Crisci KL, Greenberg SB, Wolfson BJ, Geller E, Vinocur CD. Contrast enema findings of flbrosing colonopathy. Pediatr Radiol $1997 ; 27: 315-6$.
36. Van Velzen D. Colonic strictures in children with cystic fibrosis on low-strength pancreatic enzymes. Lancet 1995;346:499-500.

37. Sheldon CD, Hodson ME, Carpenter LM, Swerdlow AJ. A cohort study of cystic fibrosis and malignancy. Br J Cancer 1993;68:1025-8.

38. Chaun H, Paty B, Nakielna EM, Schmidt N, Holden JK, Melosky B. Colonic carcinoma in two adult cystic fibrosis patients. Can J Gastroenterol 1996;10:440-2.

39. British Columbia Cancer Agency Annual Report 1993-1994. Vancouver: British Columbia Cancer Agency, 1995:33.

40. Hansen S, Hennessey R, Freitag AP, Armstrong D. Iron deficiency in adult cystic fibrosis patients. Pediatr Pulmonol Suppl 1999;19:298. (Abst)

41. Hassall E, Israel DM, Davidson AGF, Wong LTK. Barrett's esophagus in children with cystic fibrosis: not a coincidental association. Am J Gastroenterol 1993;88:1934-8.

42. Stead RJ, Redington AN, Hinks LJ, Clayton BE, Hodson ME, Batten JC. Selenium deficiency and possible increased risk of carcinoma in adults with cystic fibrosis. Lancet 1985;ii:862-3.

43. Peach SL, Borriello SP, Gaya H, Barclay FE, Welch AR. Asymptomatic carriage of Clostridium difficile in patients with cystic fibrosis. J Clin Pathol 1986;39:1013-8.

44. Pokomy CS, Bye PTP, MacLeod C, Selby WS. Antibiotic-associated colitis and cystic fibrosis. Dig Dis Sci 1992;37:1464-8.

45. Binkovitz LA, Allen E, Bloom D, et al. Atypical presentation of Clostridium difficile colitis in patients with cystic fibrosis. AJR Am J Roentgenol 1999;172:517-21.

46. Shell R. Pseudomembranous colitis complications in a patient with CF. Pediatr Pulmonol Suppl 1999;19:30.

47. Lloyd-Still JD. Co-existing gastrointestinal disorders in cystic fibrosis. Pediatr Pulmonol Suppl 1991;2:95-6.

48. Gabriel SE, Brigman KN, Koller BH, Boucher RC, Stutts MJ. Cystic fibrosis heterozygote resistance to cholera toxin in the cystic fibrosis mouse model. Science 1994;266:107-9. 


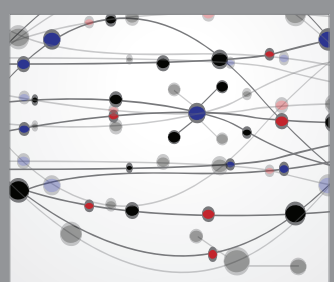

The Scientific World Journal
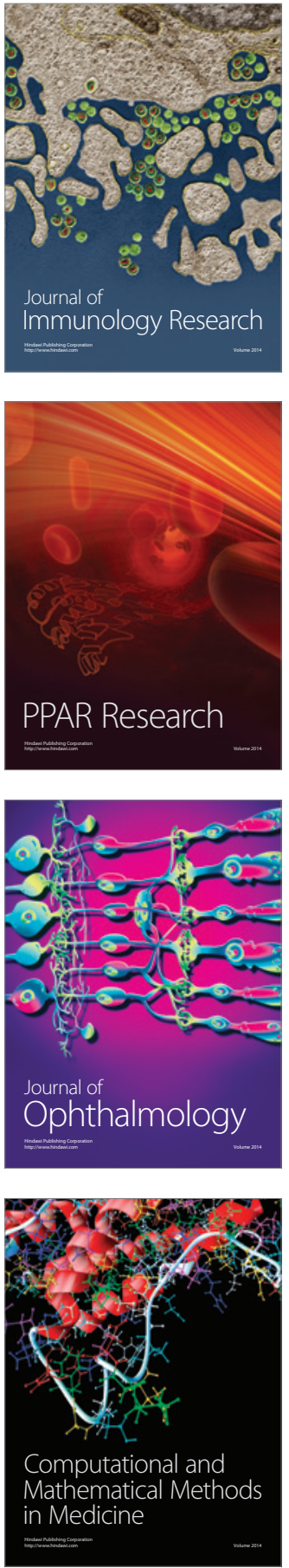

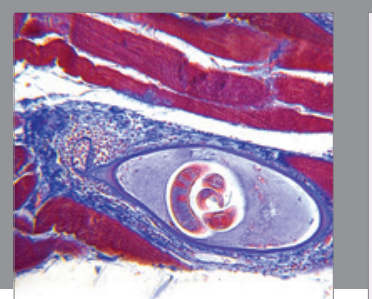

Gastroenterology Research and Practice

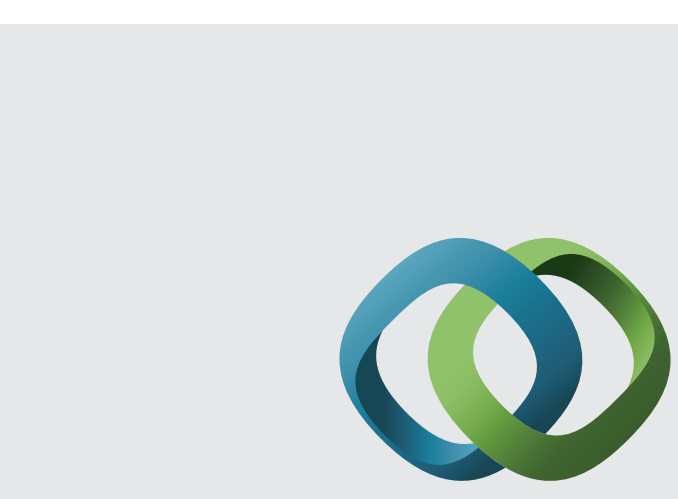

\section{Hindawi}

Submit your manuscripts at

http://www.hindawi.com
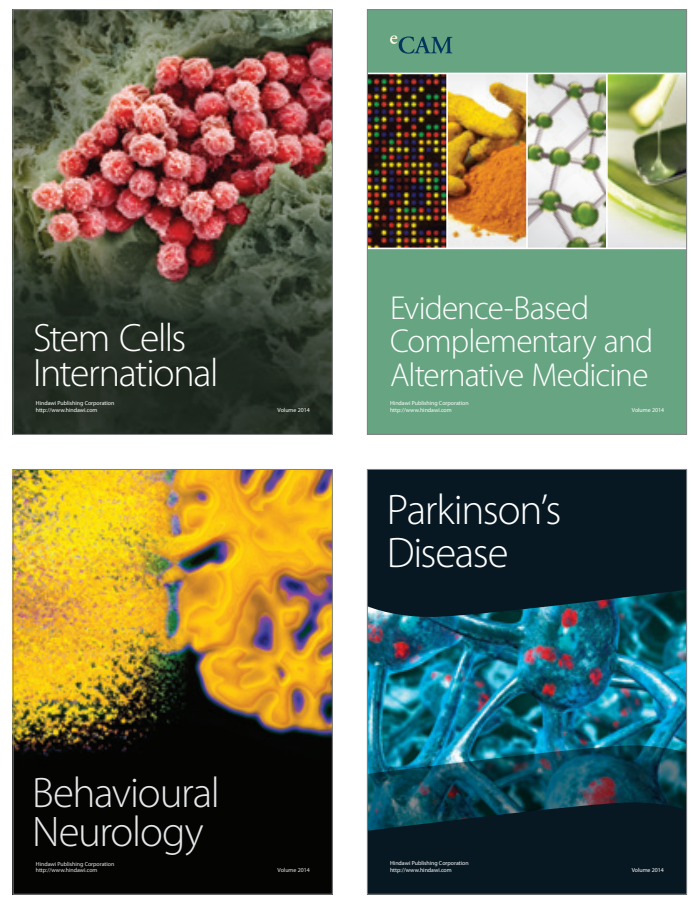
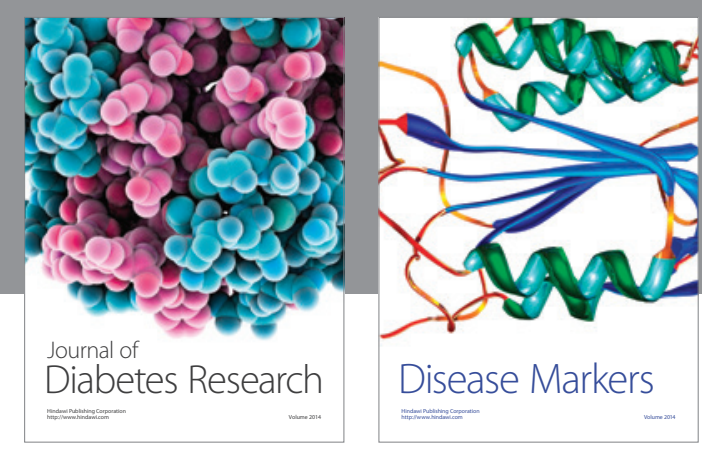

Disease Markers
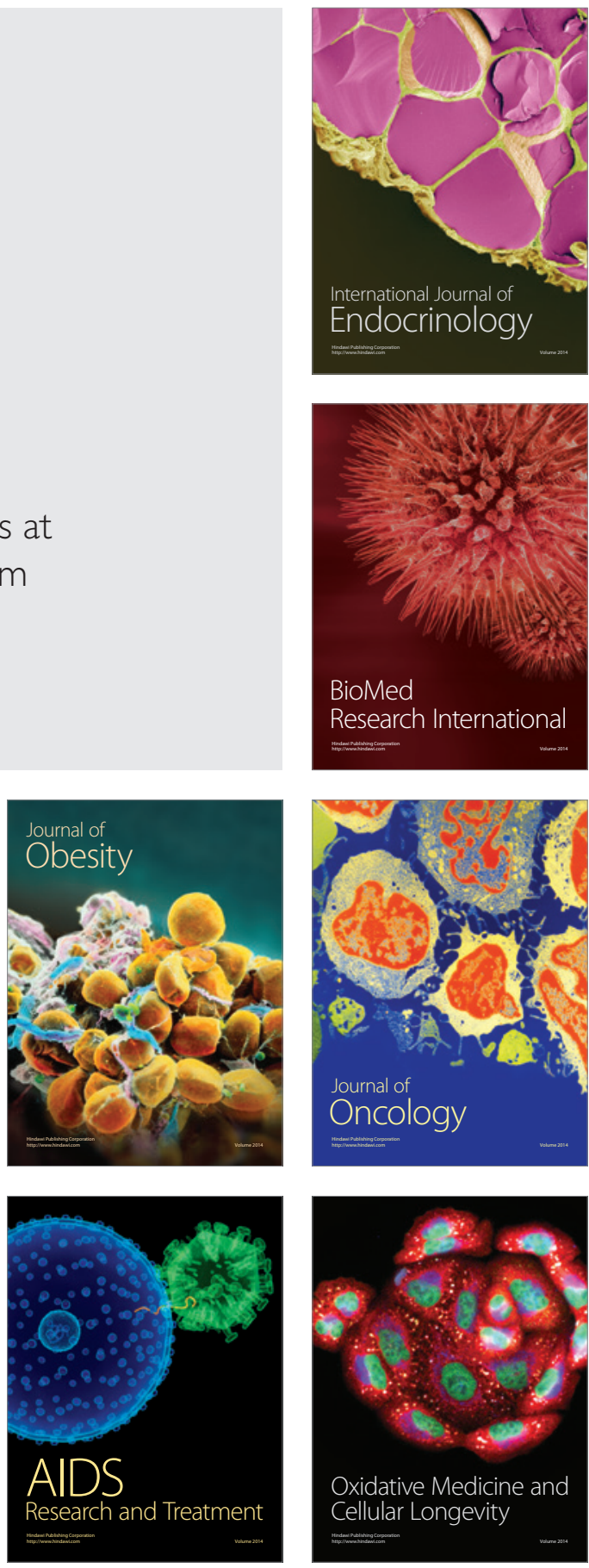